\title{
Naamkunde als discipline
}

\author{
Hans Bennis
}

\section{Naamkunde en het publiek ${ }^{1}$}

Het Meertens Instituut (KNAW) heeft sinds januari 2000 een website waarop een aantal naamkundige bestanden te vinden zijn. De elektronisch beschikbare informatie betreft op dit moment drie grote bestanden:

- de Nederlandse Familienamen Databank (NFD)

http://www.meertens.knaw.nl/NFD/nfd.html

- de Nederlandse Voornamen Databank (VNB)

http://www.meertens.knaw.nl/voornamen/VNB/

- Namen en Naamkunde in Nederland en Elders (NNN, sinds 1-12003)

http://www.meertens.knaw.nl/nnn/

Men kan op deze website informatie opvragen over de betekenis, de oorsprong en de verspreiding van familienamen (NFD), de betekenis van voornamen (VNB) en literatuur over namen en naamkundige onderwerpen $(\mathrm{NNN})$. Daarnaast bevat de website veel extra informatie over voornamen, achternamen, maar ook over het onderzoek naar straatnamen (urbane toponiemen) etc. De Meertens-website heeft als doel om informatie te bieden over de verschillende onderwerpen die op het Meertens Instituut worden bestudeerd. Deze informatie is vooral gericht op het publiek van geïnteresseerde leken. Een tweede doel is om informatie te verkrijgen via reacties van bezoekers, bijvoorbeeld om het inzicht in de oorsprong van familienamen te vergroten.

(1) Deze bijdrage is een aangepaste versie van de toespraak die ik op 22 november 2002 heb gehouden ter verwelkoming van de bezoekers van het Naamkundesymposium 'De naamkunde als interdisciplinaire wetenschap' op het Meertens Instituut. Ik dank Reina Boerrigter, Leendert Brouwer en Doreen Gerritzen voor opmerkingen bij een eerdere versie. 
Naamkunde is een relatief klein onderzoeksgebied binnen het instituut; ongeveer $10 \%$ van het onderzoek binnen het Meertens Instituut komt op naam van de naamkundige onderzoekers Doreen Gerritzen (vooral voornamen), Leendert Brouwer (vooral achternamen en bibliografie) en Reina Boerrigter (moderne toponiemen). In het verleden is gebleken dat er bij het publiek een grote belangstelling bestaat voor naamkundige onderwerpen. Tijdens open dagen wil iedereen zijn familienaam of voornaam verklaard hebben; het aantal vragen over naamkundige onderwerpen dat telefonisch, per post of per e-mail wordt gesteld, is onevenredig groot; de belangstelling bij de pers is aantoonbaar aanwezig. Deze enigszins impressionistische inschatting van de ruime publieke belangstelling voor de naamkunde kan nu ondersteund worden door een telling van het aantal bezoekers op de verschillende onderdelen van de website.

De onderstaande gegevens zijn gebaseerd op het overzicht 'Statistieken website Meertens Instituut mei 2002' dat is opgesteld door Marc van Oostendorp, die naast taalkundige/fonoloog (Meertens Instituut) en journalist (o.a. Onze Taal) ook de ontwikkelaar en de webmaster is van de Meertens-site. De Meertens-site werd in mei 2002 door ongeveer 1500 bezoekers per dag bezocht, die tezamen gemiddeld 5519 pagina's per dag opvroegen. Interessant is nu om te zien hoe de naamkundebestanden zich verhouden tot andere delen van de website. Hieronder geef ik de top-10 van de in mei 2002 bezochte pagina's van de site www.meertens.knaw.nl (NNN stond er destijds nog niet op).

\begin{tabular}{llll}
\hline & bestand & $\begin{array}{l}\text { aantal } \\
\text { verzoeken }\end{array}$ & $\begin{array}{l}\text { \% van } \\
\text { totaal }\end{array}$ \\
\hline 1. & familienamendatabank & 64.141 & 9.96 \\
2. & voornamendatabank & 55.301 & 8.05 \\
3. & familienamendatabank-info & 40.747 & 5.93 \\
4. & voorpagina website & 18.652 & 2.72 \\
5. & voornamendatabank-info & 9.235 & 1.34 \\
6. & databanken-info & 8.962 & 1.30 \\
7. & familienamendatabank-achtergrond & 8.271 & 1.20 \\
8. & voornamendatabank-betekenis & 4.934 & 0.72 \\
9. & onderzoek & 4.885 & 0.71 \\
10. nederlands repertorium van & 3.512 & 0.51 \\
\end{tabular}


Deze top-10 is samen goed voor een derde van de bezochte bestanden in mei 2002. Slechts op de nummers 4, 6 en 9 staan bestanden die niet naamkundig van aard zijn. We zien alleen hieraan al dat meer dan $27,7 \%$ van de bezoekers aan de Meertens-website naamkundige informatie wenst. Als we de overige bestanden buiten de top-10 hierbij betrekken dan is het duidelijk dat meer dan $35 \%$ van de opgevraagde bestanden naamkundige informatie bevat. In termen van bezoekers stellen we vast dat er dagelijks meer dan 500 mensen de website bezoeken om naamkundige informatie te krijgen.

Het zou natuurlijk kunnen zijn dat de rest van de website zulke saaie, vervelende en/of onvolledige informatie bevat dat de bezoekers zich ten einde raad bij de namenbestanden melden. Dat lijkt toch allerminst het geval te zijn. De voorpagina van de Feestenbank staat op 16 met 1747 verzoeken, Pinksteren op 13 met 2489, Luilak op 26 met 618 verzoeken. Ook het bestand met foto's en teksten uit Het Bureau van J.J. Voskuil blijft ver achter met 469 verzoeken. Bedevaarten, sprookjes, de dialectsprekende kaart en graancirkels leggen het ruimschoots af tegen de namenbanken.

We kunnen concluderen dat met zeven pagina's in de top-10 en meer dan 500 bezoekers per dag de namenbestanden populair zijn.

\section{Naamkunde en de politiek}

Niet alleen bij het publiek is de belangstelling voor namen aanwezig; ook in de gemeentelijke politiek bestaat er aantoonbare interesse in namen en naamgeving. Sinds september 2002 heb ik zitting in de Straatnamencommissie van de gemeente Amsterdam, als opvolger van de oud-medewerkers van het Meertens Instituut, de naamkundigen prof.dr. D. Blok en prof. dr. R. Rentenaar. Ook voor een niet-naamkundige zoals ik, is het interessant om een kijkje in de keuken van de naamgeving te nemen. Langs deze weg is het mogelijk om inzicht te krijgen in het proces van straatnaamgeving en de waarde die daar door de bevolking, de bestuurders en de ambtenaren aan wordt toegekend. Ik had eigenlijk verwacht toe te treden tot een marginaal, maar vrolijk gezelschap waar een ieder overtuigd zou zijn van de betrekkelijk beperkte reikwijdte van de werkzaamheden van deze commissie. Deze verwachting komt echter geenszins uit. De commissie is samengesteld uit respectabele en deskundige mensen die zich serieus en vol 
overtuiging storten op naamgevingskwesties. De commissie bestaat onder meer uit een (stads)historicus, een stadsarchivaris, een vertegenwoordiger van de posterijen en verscheidene aanzienlijke ambtenaren. Ik zal hier drie punten noemen die een indicatie vormen van het belang dat aan naamgeving wordt toegekend.

Tijdens de vergadering van de Straatnamencommissie van 21 november 2002 was de wethouder van Openbare Ruimte, Hester Maij, samen met haar assistent enige tijd aanwezig om kennis te nemen van de werkzaamheden van de commissie. Zij maakte hierbij duidelijk dat de politiek overtuigd is van het belang van zorgvuldige naamgeving en onderstreepte het belang van de werkzaamheden van de commissie.

Een tweede indicatie voor de politieke interesse in naamgeving was een notitie van de Socialistische Partij Amsterdam (dd 12.6.2002) met als titel 'Coentunnel wordt Max Havelaartunnel'. In verband met de viering van 400 jaar VOC stelde de SP voor om de Coentunnel, genoemd naar de VOC-er Jan Pieterszoon Coen, om te dopen in Max Havelaartunnel. Kennelijk is de SP voldoende overtuigd van het belang van namen om ook tunnelnaamgevers langs een 'politiek-correcte meetlat' te leggen, zoals blijkt uit het volgende citaat:

"En Coens lijfspreuk luidde: "Dispereert niet, ontziet uw vijanden niet, er is in de wereld niets dat ons kan hinderen noch deren, want God is met ons." Oftewel: vernietigen, verwoesten, dood en verderf zaaien, alles ten dienste van de handel in specerijen en andere kostbaarheden, maar wel goedgekeurd door God zelve die het goed met Nederland voor had."

Op deze interpretatie van Coens lijfspreuk valt wel het een en ander af te dingen, maar waar het mij om gaat, is het feit dat de SP de naam van deze tunnel in 2002 ter discussie stelt. De laatste zin van deze notitie luidt:

"Het omdopen van de Coentunnel in Max Havelaartunnel is feitelijk niet meer dan een symbolisch gebaar, maar wel één dat recht doet aan de geschiedenis en aan de mensen die de andere kant van het koloniale verleden hebben ervaren."

Tijdens deze vergadering kwam ook de vernoeming van Han Lammers, de beroemde cq beruchte Metro-wethouder van Amsterdam, ter sprake. Indertijd werd deze wethouder ook wel aangeduid als 'de sloper van Amsterdam', 
die een deel van de oude binnenstad (Nieuwmarktbuurt) plat gegooid heeft voor de aanleg van de metro. Inmiddels is deze metro een veel gebruikt en zeer gewaardeerd vervoermiddel, dat bovendien het Meertens Instituut direct verbindt met de binnenstad. De vraag ontstond of Lammers vernoemd zou moeten worden op het Westerdokseiland, en zo ja, met een straat, een kade, een plein of een voetgangersbrug. De vragen die aldus naar voren kwamen, waren: is Lammers belangrijk genoeg om vernoemd te worden, en zo ja, hoe kunnen we de mate van zijn belangrijkheid het beste uitdrukken (plein, straat, steeg of bruggetje)?

Deze punten wijzen er op dat naamgeving wel degelijk gezien wordt als een middel om politiek te bedrijven. De vele verzoeken tot vernoeming en de uitgebreide discussies in deelraden, commissies etc. ondersteunen deze visie.

\section{Naamkunde en de wetenschap}

In schril contrast tot de bovengenoemde populariteit staat de wetenschappelijke belangstelling voor de naamkunde. Aan de universiteiten in Nederland is het vak zo goed als verdwenen. Er zijn geen vakgroepen, leerstoelgroepen, onderwijsprogramma's of andere structurele voorzieningen voor de naamkunde in Nederland. Voor zover er sprake is van universitair onderzoek en onderwijs is dit incidenteel. Ook buiten de universitaire wereld heeft de wetenschappelijke bestudering van namen geen structurele verankering. De enige wetenschappelijke voorziening voor naamkunde die er in Nederland bestaat, betreft het beperkte aantal posities aan het Meertens Instituut en de Fryske Akademy. Hoewel de naamkunde ooit één van de drie pijlers van het P.J. Meertens-Instituut was — van 1952 tot 1979 heette het 'Instituut voor Dialectologie, Volkskunde en Naamkunde' - is de naamkunde inmiddels teruggedrongen tot een tweetal structurele onderzoekersplaatsen (waarvan er maar één op structurele basis kan worden ingevuld) en een medewerker onderzoek. Of zoals bij een evaluatie in 1997 werd vastgesteld: "De formatie van het project Naamkunde is zo klein geworden dat de inbreng van de projectgroep is gemarginaliseerd."2 Ook heeft de naamkunde niet langer een eigen positie, nevengeschikt aan de dialectologie en de volkskunde. Er zijn

(2) Rapport Commissie "Toekomst P.J. Meertens-Instituut". November 1997. 
nu twee onderzoeksgroepen: Variatielinguïstiek (voorheen Dialectologie) en Nederlandse etnologie (voorheen Volkskunde). Naamkunde is formeel ondergebracht bij Variatie-linguïstiek. Deze veranderde positie is illustratief voor de huidige status van het onderzoeksterrein.

Er zijn in de afgelopen vijftien jaar verscheidene discussies gevoerd over de positie van naamkunde binnen het instituut. Een centrale vraag daarbij was of naamkunde wel een eigen disciplinariteit kent. Het is duidelijk dat de doelstelling van naamkundig onderzoek nogal kan verschillen. Het onderzoek kan in eerste instantie taalkundig van aard zijn, maar ook historisch, archeologisch, (sociaal-) geografisch, etnologisch of sociaalcultureel. Als de vraagstellingen binnen de naamkunde zo ver uiteenlopen, is het de vraag of er nog wel sprake is van een discipline. Het zou heel goed kunnen zijn dat het onderzoek naar namen betekenisvol is voor uiteenlopende wetenschapsgebieden, terwijl een optelsom van dat onderzoek geen coherent beeld oplevert.

De titel van het symposium 'De naamkunde als interdisciplinaire wetenschap' suggereert dat het vak zich bevindt tussen verschillende andere vakken in. In dat geval heeft het vak een eigen positie, maar gedefinieerd als liggend tussen verschillende disciplines in. Maar zelfs dan is de positie van naamkunde niet erg helder. Het is bijvoorbeeld niet duidelijk op welke wijze onderzoek naar de populariteit van voornamen in een multi-etnische omgeving interdisciplinair aansluit bij onderzoek naar nederzettingsgeschiedenis op basis van veldnamen of bij onderzoek naar de morfologische structuur van bedrijfsnamen.

De conclusie zou daarom kunnen zijn dat de naamkunde op dit moment in Nederland niet echt een discipline is: het vakgebied heeft een beperkte omvang en een geringe wetenschappelijke traditie, de vraagstelling loopt sterk uiteen en de naamkunde kent in Nederland geen inbedding in het universitaire onderzoek/onderwijs.

\section{Naamkunde en de toekomst}

Het lijkt verstandig om ons op dit moment te bezinnen op de vraag naar de status van de naamkunde binnen de geesteswetenschappen in Nederland. In het Meertens Instituut gaan er al enige tijd stemmen op om een dergelijke discussie in gang te zetten. Als inhoudelijk buitenstaander, maar tevens als 
institutioneel betrokkene ondersteun ik zo'n discussie van harte. Van groot belang is dat het forum van naamkundigen hierbij een helder geluid laat horen.

Aan de ene kant zou dat geluid kunnen uitmonden in de stelling dat naamkunde geen disciplinaire eenheid vormt en dat het naamkundig onderzoek zou kunnen opgaan in andere disciplines. Er bestaat dan geen disciplinair verband meer tussen bijvoorbeeld historisch onderzoek gericht op veldnamen, sociaal-cultureel onderzoek op het terrein van de voornaamkeuze en taalkundig onderzoek op het terrein van bedrijfsnamen.

Aan de andere kant lijken er goede redenen te zijn om een interdisciplinair of multidisciplinair vak naamkunde te handhaven. In dat geval ligt er een taak bij de naamkundigen om hun vak op een duidelijke en uniforme manier uit te dragen. Vandaar dat ik de naamkundigen hierbij uitnodig en uitdaag om hun standpunt duidelijk te maken. Als naamkunde als disciplinaire eenheid moet worden gehandhaafd en moet worden ondersteund, op grond van welke overwegingen kan dit dan het best worden onderbouwd? Een heldere positionering van het vakgebied is onontbeerlijk. Er bestaat nu nog een minimale infrastructuur waarop kan worden voortgebouwd: het tijdschrift Naamkunde, het Naamkunde-symposium, de bestaande databanken en de enkele onderzoeker aan instituut of universiteit. Tezamen zou dit de basis kunnen vormen van een beweging die tot doel heeft de wetenschappelijke discipline naamkunde nieuw leven in te blazen.

Als de naamkundigen nu niet hun standpunt met kracht naar voren brengen, dan vrees ik het ergste. In een tijd waarin het wetenschappelijk onderzoek binnen de geesteswetenschappen ernstig onder druk staat en waarin traditionele vakgebieden binnen de letteren ook nog eens te lijden hebben van modieuze vakken als televisiewetenschap, communicatiekunde of cognitiewetenschappen, is het geenszins vanzelfsprekend dat er investeringen worden gedaan in het onderhouden van naamkunde als disciplinair, interdisciplinair of multidisciplinair onderzoeksterrein. Ik zou dus willen zeggen: Dames en heren naamkundigen, wijs ons op het belang en de plaats van de naamkunde in het wetenschappelijk bestel! 